\title{
Türkiye'de Metal Sektöründe Meydana Gelen İş Kazalarının Analizi
}

\author{
Analysis of Work Accidents Caused in the Metal Sector in Turkey
}

\author{
Esma Nur GÜLLÜOĞLU ${ }^{1,2}$ [D, Arif Nihat GÜLLÜOĞLU ${ }^{1}$ (D) \\ ${ }^{1}$ Marmara Üniversitesi, Fen Bilimleri Enstitüsü, İs Güvenliği Anabilim Dall, 34722, İstanbul, Türkiye \\ ${ }^{2}$ İstanbul Teknik Üniversitesi, Fen Bilimleri Enstitüsü, Tekstil Mühendisliği Anabilim Dall, 34469, İstanbul, Türkiye
}

$\ddot{O} z$

Metal sektörü dünyada olduğu kadar ülkemizde de önemli bir sektör konumundadır. Üstün özellikleri nedeniyle, teknolojik gelişmelere bağlı olarak kullanım alanları hızla yaygınlaşan metaller endüstride geniş bir uygulama alanına sahiptir. Bütün sanayilerin lokomotifi niteliğinde olan metal sektörü, barındırdığı iş gücü ve ekonomik büyüklüğü bakımından Türkiye'nin en önemli sanayi kolu durumundadır. Günümüzde her alanda yaşanan hızlı değişim ile üretim ve rekabet artmakta, iş kazaları sonucu çalışanların sağlığına ve iş güvenliğine yönelik tehlikelerde çoğalmaktadır. Ülkemizde yaşanan iş kazaları sayısı bakımından metal sanayi iş kazası yoğunluğunun en yüksek olduğu sektördür. Bu çalışmada 2007-2016 yılları arasında Türkiye genelinde meydana gelen iş kazaları ile metal sektöründe yaşanan kazalara ait veriler incelenerek analiz edilmiştir. Ayrıca, Türkiye metal sektörü iş kazaları verileri Avrupa birliği üye ülkeleri ile karşılaştırılmıştır.

Anahtar Kelimeler: Metal Sektörü, İş Güvenliği, İş Kazaları, Kaza İstatistikleri, İstihdam

\begin{abstract}
Metal sector is an important sector in our country as well as in the world. Due to their superior properties, the use of metals which are rapidly spreading due to technological developments has a wide application area in industry. Metals sector, which are the locomotive of the whole industry, which is keeping in the case of the labor force and economic size in terms of Turkey's most important industries. Today, with the rapid change experienced in every field, production and competition increase, and as a result of occupational accidents, and the risks to the health of workers and work safety are increasing. In terms of the number of occupational accidents in our country, metal industry is the sector with the highest occupational accident intensity. In this study, between the years 2007-2016 were analyzed by examining the data on occupational accidents in Turkey and in the metal industry. Besides, Turkey metal sector accidents at work were compared with data from member countries of the European Union.
\end{abstract}

Keywords: Metal Sector, Occupational Safety, Work Accidents, Accident statistics, Employment

\section{I.GÍRIŞ}

İş Sağlığı ve güvenliği, insan hayatı söz konusu olduğunda küresel boyutta bir sorundur. Çalışma hayatının en önemli sorunu olan iş kazaları ve meslek hastalıklarını önlemede gerekli tedbirleri almak bir insanlık görevidir. Uluslararası Çalışma Örgütü (ILO) verilerine göre her yıl işle ilgili kaza ve hastalıklar sonucu 2,78 milyondan fazla kişi hayatını kaybetmektedir. Bu ise günde yaklaşık 7,6 bin kişinin iş kazaları ve meslek hastalıkları nedeniyle öldüğünü göstermektedir. Ayrıca her yıl dünyada 374 milyon kişinin ölümcül olmayan iş kazası ve meslek hastalığına maruz kaldığı ve bunların çoğunun işten uzun süreli geçici işgücü kaybıyla sonuçlandığı bildirilmektedir. İş kazaları ve meslek hastalıklarının yarattığı ekonomik yük, her yıl küresel gayri safi milli hasılanın (GSMH) \%3,94’ünü teşkil etmektedir [1]. 
Metal sektörü, Gayri Safi Milli Hasılanın \%3'üne, endüstriyel sektörlerdeki toplam istihdamın $\% 2$ 'sine ve toplam ihracatın \%12' sine sahip bulunmaktadır. Bu yönü ile metal sektörü en çok ihracat yapan sektörler arasında 3'üncü s1rada yer almaktadır [2].

Ana metal sanayi sektörü Türkiye'nin kalkınmasına katk1 sağlayan en önemli sektörlerden biri olarak öne çıkmakta ve dış ticaret açısından rekabet gücü sıralamasına göre diğer 34 ana sektör içinde 9'uncu sırada yer almaktadır [3]. Demir çelik sektörü, 2017 yılında 18,3 milyon ton demir çelik ürünü ihracatı yaparak, ülkemize 13.8 milyar dolar gelir ile toplam ihracatımızın \%8,5'ini teşkil etmektedir. Sektör, 2017 yılı itibarıyla net ihracatçı konumundadır. 2017 yılı verilerine göre çelik üretiminde dünyadaki 65 çelik üreten ülke arasında 8'inci, Avrupa'da ise Almanya'dan sonra 2'nci s1rada bulunan ülkemiz, Ortadoğu ve Kuzey Afrika'nın en büyük çelik üreticisi konumundadır. Sektör, 45.000 kişiye istihdam sağlamaktadır. Demir çelik sektörü, diğer sektörlere girdi sağlayan yapısı ile lokomotif rol üstlenmektedir [4].

Sektörün teknolojik acıdan sürekli gelişme göstermesi, dünya ticaretindeki payının yüksekliği, büyük işgücü istihdam etmesi, dünya genelinde toplam ekonomik faaliyetlerin artması ve ülke ekonomilerindeki büyümenin bir yansıması olarak demir çelik ürünleri talebinin her geçen gün büyük bir hızla artması dünya toplam çelik üretimini de artırmaktadır [2].

Çalışma hayatında mevcut sektörler, tehlike ve riskler açısından değerlendirildiğinde metal, maden, inşaat ve tekstil sektörü ön sıralarda yer almaktadır. Metal sektörü, yoğun bir rekabetin yaşandığı ve esnek çalışma biçimlerinin yaygın olarak kullanıldığı demir - çelik, döküm, ham çelik, ferro alaşımlar, demir dışı metaller - alüminyum ve bakır başta olmak üzere ana sanayi kollarını içinde barındırması sebebiyle ülkemizde motor sektör olma özelliğini taşımaktadır. Yapısı gereği içerisinde bulundurduğu risk ve tehlikeler nedeniyle bilgi, deneyim, uzmanlık ve sürekli denetim gerektiren ağır ve tehlikeli sektörlerin başında gelmektedir [5].

Metal sektöründe yaygın olarak cevher ve hurda eritme ve arıtma, döküm işleri, sıcak veya soğuk dövme, presleme, kaynaklı birleştirme ve metal kesme, sinterleme, talaşlı imalat ve tornacilık gibi temel metal işleme teknikleri uygulanmaktadır. Son ürünü elde edinceye kadar taşlama, parlatma, zımparalama, yüzey işleme ve kaplama işlemleri (elektro-kaplama, galvanizleme, isıl işlem, eloksal, toz boya ve benzeri) gibi çeşitli teknikler de kullanılmaktadır [6]. Metallerin işlenmesi sırasında çeşitli zararlı tozlar, gazlar, dumanlar ve diğer kimyasallara maruziyet, sıcak stresi, gürültü, vibrasyon, sıkışma, kesici ve delici uçlardan kaynaklı yaralanmalar, parlama, iyonize ve kızılötesi radyasyon, elektrik tehlikeleri, sırt ve üst ekstremite hasarları, göz ve vücut yaralanmaları, yanıklar, tekrarlanan gerilme hasarları, akciğer hastalıkları, kas iskelet sistemi problemleri, solunum, cilt ve sistemik toksik etkileri ile oldukça sık karşılaşı1ır [7].

Yapılan bir çalışmada, metal işleme endüstrisindeki güvenlik önlemlerinin zamanla arttırılması sonucu olarak, kaza göstergeleri değerlerinin azalan eğilimde gerçekleşmekte olduğu ifade edilmektedir. Yaz aylarında ve gece vardiyalarında kaza sayılarında artış olduğunu, genelde kazaların yaklaşık \%62'sinin uzuvları etkilediği, \%40,9'unun kesik sıyrık gibi yüzeysel yaralanmalara neden olduğu, $\% 45,5$ 'in yanlış hareketler ve küçük aletlerin kullanımından, \%62.5'inde ise makinelerin kazalara katkıda bulunduğu belirtilmektedir. Yaralanma nedenleri ile ilgili olarak genç ve daha az deneyime sahip çalışanlar, sigara içme ve çiğneme alışkanlığ 1 olanlar ile obez çalışanlar gibi bazı yüksek riskli grupların kaza riskini artırdı ̆̆ı vurgulanmaktadır [8].

Türkiye İşverenleri Metal Sanayicileri Sendikası (MESS) iş sağlığı ve güvenliği kültürünü yaygınlaştırmak amacıyla her yıl üyeleri arasında gerçekleştirdiği İş Kazaları ve Meslek Hastalıkları İstatistikleri araştırmasının 2016 yılı sonuçlarına göre iş kazaları en fazla Mart ayında meydana gelmiştir. Gün bazında kaza en fazla Salı günleri yaşanırken, saat bazında 3'üncü iş saatinde meydana gelmiştir. Kazalı çalışanların dağılımında ise \%66'sını evlilerin oluşturduğu, yaş ve işyerindeki kıdem açısından \%28'inin 2-4 kıdem yılı aralığında, \%48'inin ise 25-35 yaş aralığında olduğu belirlenmiştir [9].

2016 yılı istatistiklerine göre 20.616 iş kazası sayısı ile fabrikasyon metal ürünleri imalatı (makine ve teçhizat hariç) tüm gruplar içinde en çok kaza yaşanan faaliyet grubu olarak karşımıza çıkmaktadır. Bu sektörün en çok iş kazası yaşanan sektör olmasının sebepleri olarak, yoğun bir üretim alanını kapsaması, tam otomasyonla vardiya usulü çalışılması, yoğun olarak makinelerle çalışılmasından kaynaklı arıza ve teknik hataların sık yaşanması gösterilmektedir [10].

Metal çalışanları üzerinde yapılan diğer bir çalışmada, iş kazalarının nedeni, \%44 yetersiz kişisel koruyucu ekipman kullanımı, \%38 dikkatsizlik, \%18 kişisel nedenler ile makine ve tezgahlarda güvenlik önlemlerinin alınmaması olarak belirtilmiş, iş kazalarının çoğunlukla kişisel koruyucu ekipmanın kullanımındaki eksiklikten ve yetersiz mesleki eğitimden kaynaklandığı ortaya konulmuştur [11].

Norveç’te metal sektörü çalışanları arasında yapılan bir araştırmada göz yaralanmalarına karşı göz korumasının kullanılmasının zorunlu hale getirilmesi ile göz yaralanmalarını önlemede büyük katkısı olduğu tespit edilmiştir [12].

Metal sektöründe kişisel koruyucu donanımların kullanımı konusunda yapılan çalışmada yüz koruyucuları, göz 
ve işitme koruyucuları ve ayak koruyucuları kullananların oranının diğer sektörlere göre daha fazla olduğu tespit edilmiştir. Çalışmaya katılanların anket sonuçları değerlendirildiğinde; \%92,6's1 işyerindeki risklerin farkında olduklarını, kişisel koruyucu donanım (KKD) seçiminde görüşlerinin alınma oranının \%91,2 olduğu; KKD'lerin muhafazası ve saklanmasında özel bir dolap bulunma oranını \%26,5 olduğu, çalışanların \%95,6 'lık bölümü KKD kullanımının koruma sağladığına inandıklarını, KKD'nin doğru ve etkin kullanımına yönelik katılımcıların \%94,1 oranında ilgili eğitimin alındığı ancak KKD'ların kullanım kılavuzunun okunma düzeyinin \%52,9 kaldığı tespit edilmiştir. Ancak çalışma kapsamında gerçekleştirilen saha ziyaretlerinde anket sonuçlarında görülenden daha düşük bir bilinç düzeyi ve kullanım oranı gözlendiği belirtilmiştir [13].

Bu çalışmada 2007 - 2016 yılları arasında SGK tarafından yayınlanan istatistikler incelenerek elde edilen veriler ile Türkiye geneli ve metal sektöründe meydana gelen iş kazalarının değerlendirmesi, işyeri ve çalışan sayılarına göre ve uluslararası kabul görmüş ölçütlere göre gerekli hesaplamalar yapılarak analiz edilmiştir. İş teftişleri verilerine göre Türkiye geneli ve metal sektöründeki iş sağlığı ve güvenliği teftişleri de incelenmiştir. Metal sektöründe yaşanan iş kazası sıklık değeri Avrupa Birliği ülkeleri ile karşılaştırılmiştır.

\section{II.MATERYAL ve YÖNTEM}

$\mathrm{Bu}$ çalışmada SGK tarafından her y1l yayınlanan istatistik yıllıkları kullanılarak 2007 - 2016 yılları arasında (10 yıllık veriler) Türkiye genelinde faaliyet gösteren sektörlerin toplamı ile metal sektöründe meydana gelen iş kazalarına ait istatistiksel bilgiler ve veriler uluslararası kabul görmüş parametreler açısından incelenerek analiz edilmiştir. Elde edilen veriler ile Uluslararası Çalışma Örgütü (ILO), Avrupa Birliği İstatistik Ofisi (EUROSTAT) ve Sosyal Güvenlik Kurumu (SGK) tarafindan belirlenen genel kaza sıklığı, ölümlü kaza sıklığı, sürekli iş görmezlik kaza sıklığı, geçici iş görmezlik kaza sıklığı, standardize iş kazası oranı, iş kazası sıklık hızı ve iş kazası ağılık hızı, ölçütlerine göre hesaplanmalar yapılarak son 10 yıllık periyotta Türkiye geneli ve metal sektöründe meydana gelen değişimlerin durumu hem grafiksel hem de tablolar yardımı ile incelenerek değerlendirilme yapılmaya çalışılmıştır.

Metal sektörü, Avrupa Birliği İstatistik Ofisi tarafindan oluşturulan NACE Rev.2 Altılı Ekonomik Faaliyet Sınıflamasına göre 01-99 arasındaki rakamlarla iki haneli olarak ifade edilen sınıflamada; 24-Ana metal sanayi sektörü ve 25-Fabrikasyon metal ürünleri imalatı (makine ve teçhizat hariç) sektörü olarak gruplandırılan bölümlerin toplamı olarak değerlendirilmiş ve çalışmada bu alanlardaki veriler kullanılmıştır. 26/12/2012 tarihli ve 28509 sayılı Resmi Gazete' de yayımlanarak yürürlüğe giren "İşs Sağlı̆̆ı ve Güvenliğine İlişkin İşyeri Tehlike Sınıfları Tebliği "ne göre metal sektöründeki işyerlerinin ekonomik faaliyet alanlarına ilişkin tehlike sınıfları ve alt sektör sayıları Tablo 1'de verilmiştir [14].

Tablo 1. Metal Sektörü Ekonomik Faaliyet Sinıflaması ve Alt Sektörler Bazında Tehlike Sınıfları Dağılımı[14]

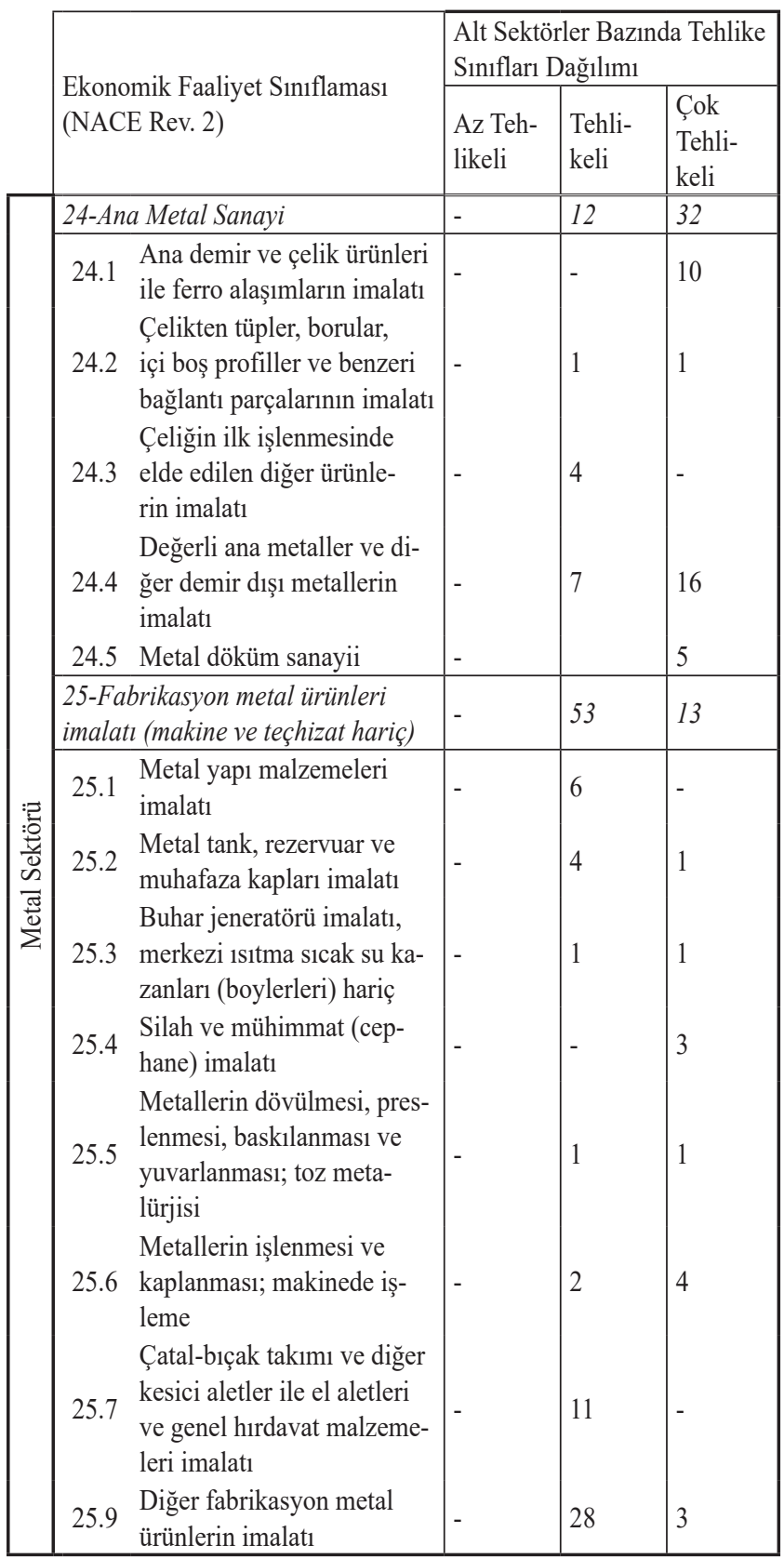

Aynı sektördeki çalışan sayısı her ülkede farklılık göstermektedir. Bu nedenle ülkelerin ekonomik faaliyetlerine 
ilişkin istatistiki bilgilerinin birbirleri ile anlamlı karşılaştırma yapılabilmesi için istihdam boyutundaki farklılıkların, çalışan sayısındaki değişikliklerin ve çalışma saatlerindeki çeşitlilik gibi faktörlerin dikkate alınması gerekir. Önemli olan, meydana gelen iş kazası sayısı değil incelenen çalışma gurubundaki oranıdır. Bu farklılıkları dikkate alan, hem ulusal hem de uluslararası düzeydeki bilgilerin karşılaştırılmasinda kullanılan oranlar, ILO, EUROSTAT ve SGK tarafindan belirlenen aşağıdaki ölçütlere göre hesaplanarak [15-26] tablolar ve eğrisel değişim grafikler ile yorumlanmaya çalışılmıştır.

- Kaza Sıklı̆̆ı: Bir yıl içerisinde, istihdamda yer alan her 100.000 çalışan başına düşen iş kazası sayısı olarak tanımlanmaktadır. Bu çalışmada, oluşan kazaların büyüklüğünü değerlendirebilmek için iş kazası sonucu oluşan; genel iş kazası, geçici iş görmezlik, sürekli iş görmezlik ve ölümlü iş kazası olmak üzere farklı kaza sıklığı ölçütleri hesaplanmıştır.

- Standardize İş Kazası Oranı: Bir yıl içerisinde, incelenen faaliyet kolunda meydana gelen iş kazası sayısının o faaliyet kolundaki beklenilen kaza sayısına oranının yüzdesel ifadesi olarak tanımlanmaktadır.

- İş Kazası Sıklık Hızı: Bir yıl içerisinde çalışılan her 1.000.000 iş saatine karşı1lık gelen kaza sayısı olarak tanımlanmaktadır.
- İş Kazası Ağırlık Hızı: Bir yıl içerisinde çalışılan her 1.000 .000 saatte iş kazası nedeniyle kaybedilen iş günü sayısı olarak tanımlanmaktadır.

Bu çalışmada 2007 - 2016 yılları arasında metal sektörünün işyeri sayısı ve çalışan sayısı bakımından işyeri büyüklüğüne göre dağılımı SGK tarafından yayınlanan istatistiki bilgiler ile değişim sonuçları tablo ve grafikler halinde değerlendirilmeye çalışılmıştır. Ayrıca Çalışma ve Sosyal Güvenlik Bakanlı̆̆ı' nca yayınlanan "Çalışma Hayatı İstatistikleri”nde yer alan İş Teftişleri verilerine göre [27-33], Türkiye geneli ve metal sektöründe yıllar bazında yapılan iş sağlığ1 ve güvenliği teftiş sayıları işyeri ve çalışan sayısına göre incelenerek değerlendirilmiştir.

\section{III.BULGULAR ve TARTIŞMA}

2007 - 2016 yılları arasında Sosyal Güvenlik Kurumunun yıllık istatistiki verilerinden elde edilen bilgilere göre, Türkiye geneli ve metal sektöründe istihdam edilen sigortalı çalışan sayıları Tablo 2'de verilmiştir. Tüm sektörlerin toplamını veren Türkiye geneli çalışan sayısında sürekli artış gözlenirken, ana metal sanayinde 2012 yılı ve sonrasinda azalış göstermektedir. Fabrikasyon metal ürünleri imalatında ise genelde artış olmasına rağmen yıllar içinde değişkenlik göstermektedir.

Tablo 2. Sigortalı Çalışan Sayıları [17-26]

\begin{tabular}{|l|l|l|l|l|l|l|l|l|l|l|}
\hline Ylllar & 2007 & 2008 & 2009 & 2010 & 2011 & 2012 & 2013 & 2014 & 2015 & 2016 \\
\hline Ana metal sanayi & 88.176 & 118.460 & 118.109 & 145.014 & 158.175 & 164.795 & 159.842 & 151.253 & 149.301 & 145.268 \\
$\begin{array}{l}\text { Fabrik.Metal Ürün. } \\
\text { (Mak.Tec.Har) }\end{array}$ & 307.991 & 354.262 & 324.756 & 323.651 & 357.757 & 357.841 & 376.076 & 395.114 & 393.638 & 383.438 \\
\hline Metal Sektörü Topl. & 396.167 & 472.722 & 442.865 & 468.665 & 515.932 & 522.636 & 535.918 & 546.367 & 542.939 & 528.706 \\
\hline Türkiye Geneli & 8.505 .390 & 8.802 .989 & 9.030 .202 & 10.030 .810 & 11.030 .939 & 11.939 .620 & 12.484 .113 & 13.240 .122 & 13.999 .398 & 13.775 .188 \\
\hline
\end{tabular}

Şekil 1'de çalışan sayıları bakımından iş yeri büyüklügüne göre metal sektöründeki istihdam Türkiye geneli ile karşılaştırıldığında; sektördeki istihdamın \%53'ünün çalışan sayısı elliden fazla olan orta ve büyük ölçekli işyerlerinden sağlanırken bu oranın Türkiye genelinde $\% 41$ olduğu görülmektedir.

Metal sektöründe istihdamın alt sektör dağılımı Şekil 2'de incelendiğinde, çalışanların \%73'ü fabrikasyon metal ürünleri imalatı sanayinde, $\% 27$ 'si ise ana metal sanayinde yer almaktadırlar. Fabrikasyon metal ürünleri imalatı sanayinde en büyük istihdam küçük ve orta ölçekli işyerlerinden sağlanırken ana metal sanayinde istihdam orta ve büyük ölçekli işyerlerinde yoğunlaşmaktadır.

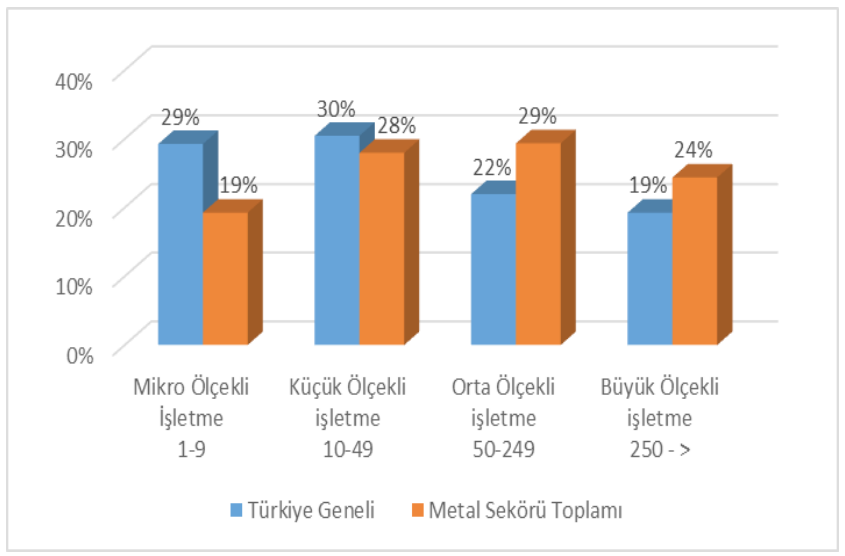

Şekil 1. Çalışanların İşyeri Büyüklügüne Göre Dağglımı [26] 


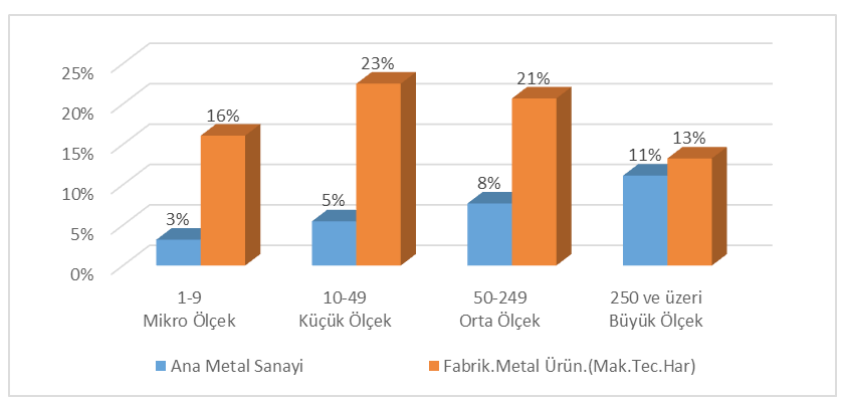

Şekil 2. Metal Sektöründe İstihdam Dağılımı [26]

İşyeri sayıları bakımından, Sosyal Güvenlik Kurumunca yayınlanan yıllık istatistik verilerine göre 2007 - 2016 yılları arasında fabrikasyon metal ürünleri imalatı sanayinde son yıllarda artış gözlenirken, ana metal sanayinde 2012 y1lından itibaren azalma gözlenmektedir. Türkiye geneli işyeri sayılarında ise sürekli artış görülmektedir (Tablo 3).

İşyerlerinin çalışan sayıları bakımından büyüklüklerini gösteren grafik Şekil 3'de verilmiştir. Buna göre Türkiye genelindeki işyerlerinin $\% 98$ 'i, metal sektöründeki işyerlerinin ise \%96'sı çalışan sayısı elliden az olan mikro ve küçük ölçekli işletme niteliğindedir. Metal sektöründe bulunan işletmelerin \%79'u bünyesinde 1-9 kişi çalışanı bulunan mikro ölçekli işletme niteliğinde iken, \%17'si 10-49 arasında çalışanı bulunan küçük ölçekli işletme niteliğindedir.

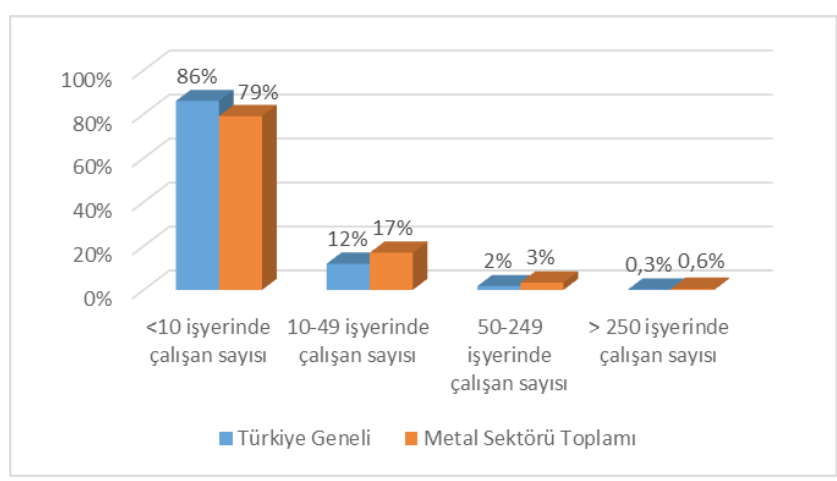

Şekil 3. Çalışan sayısına göre işyeri büyüklüğü dağılımı [26]

Metal sektöründe işletme sayısı Şekil 4'de görüldüğü üzere en fazla fabrikasyon metal ürünleri imalatı sektöründe olup, sektör içerisindeki pay1 \%82'dir. Bunun da \%66'sı yapısında 1-9 çalışanı bulunan mikro ölçekli işletmelerden oluşmaktadır.

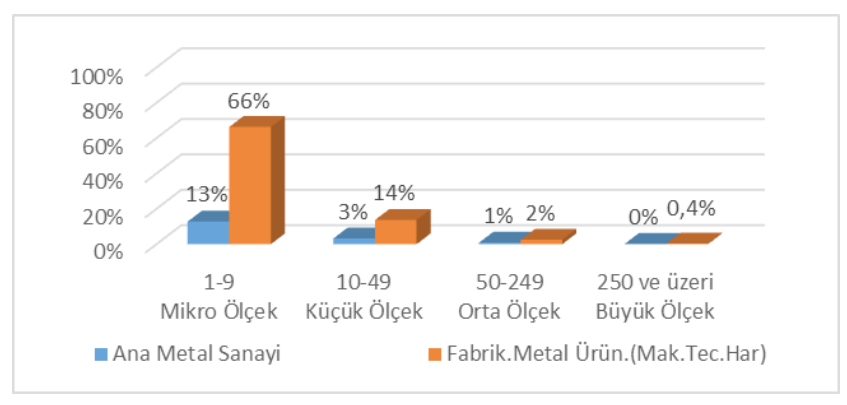

Şekil 4. Metal Sektöründe İşyeri Sayılarının Dağılımı [26]

2007 - 2016 yılları arasında Türkiye genelinde tüm sektörler toplamı ve metal sektöründe çalışan sayısı, iş kazası sayıları ve hesaplanan iş kazası sıklığı ile yıllar bazındaki yüzdesel değişimleri Tablo 4'de verilmiştir. Tablo 4 incelendiğinde, verilen istatistiki bilgilere göre çalışan sayısında son 10 yılda Türkiye genelinde belli bir düzende $\% 61,95$ 'lik artı̧̧ gerçekleşirken, metal sektöründe dalgalanmalar göstererek \%74,93'lük artış görülmektedir. 2016 yılı için metal sektörü 528.706 çalışanı ile tüm ülke işgücünün yaklaş1k \%3,84'sini istihdam ederken, 33.697 kaza sayısı ile ülke genelinin \%11,78 ine tekabül etmektedir. Türkiye geneli ve metal sektöründe 2011 yılına kadar iş kazası sayılarında genelde bir azalma görülmesine rağmen 2013 yllında metal sektöründe \% 132 ve Türkiye genelinde $\% 155^{\prime}$ lik bir artış gerçekleşmiş̧ir.

Metal sektöründe çalışan sayıları ve iş kazaları Şekil 5 de görüleceği üzere kendi içinde değerlendirildiğinde, Ana Metal Sanayi dalında \%27 çalışan olmasına rağmen kaza oranı \%39 olarak gerçekleşmiştir.

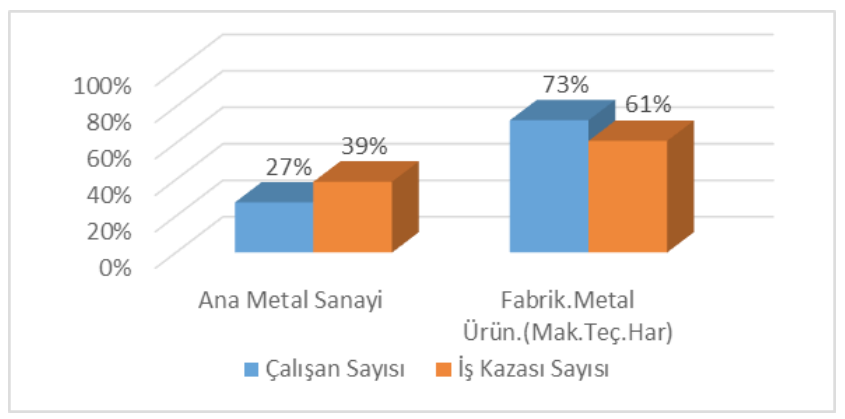

Şekil 5. Metal Sektöründe İş Kazaları Dağılımı [26] 
Tablo 3. Sektörlerde İşyeri Sayıları [17-26]

\begin{tabular}{|l|l|l|l|l|l|l|l|l|l|l|}
\hline Y1llar & 2007 & 2008 & 2009 & 2010 & 2011 & 2012 & 2013 & 2014 & 2015 & 2016 \\
\hline $\begin{array}{l}\text { Ana Metal Sanayi } \\
\begin{array}{l}\text { Fabrik.Metal Ürün. } \\
\text { (Mak.Tec.Har) }\end{array}\end{array}$ & 2.437 & 6.054 & 7.046 & 8.612 & 9.059 & 9.063 & 8.918 & 7.830 & 7.607 & 7.270 \\
\hline Metal Sektörü Topl. & 29.920 & 41.030 & 39.981 & 38.104 & 39.605 & 40.101 & 41.266 & 42.943 & 42.986 & 42.479 \\
\hline Türkiye Geneli & 1.116 .638 & 1.170 .248 & 1.216 .308 & 1.325 .749 & 1.435 .879 & 1.538 .006 & 1.611 .292 & 1.679 .990 & 1.740 .187 & 1.749 .240 \\
\hline
\end{tabular}

Tablo 4. İş Kazası Sıklı̆̆1 [17-26]

\begin{tabular}{|c|c|c|c|c|c|c|c|c|c|c|c|c|}
\hline \multirow[b]{2}{*}{ YILLAR } & \multicolumn{6}{|c|}{ Türkiye Geneli } & \multicolumn{6}{|c|}{ Metal Sektörü } \\
\hline & \begin{tabular}{|l} 
Çalışan Sa- \\
yısı
\end{tabular} & Değiş. \%'si & \begin{tabular}{|l|} 
İş Kazası \\
Sayısı
\end{tabular} & Değiş. \%'si & $\begin{array}{l}\text { İş Kazası } \\
\text { Sıklı̆ğ }\end{array}$ & Değiş. \%'si & $\begin{array}{l}\text { Çalışan } \\
\text { Sayıs1 }\end{array}$ & Değiş. \%'si & $\begin{array}{l}\text { İş Kazası } \\
\text { Sayıs1 }\end{array}$ & Değiş. \%'si & \begin{tabular}{|l} 
İş Kazası \\
Sıklığı
\end{tabular} & Deği. \%'s \\
\hline 2007 & 8.505 .390 & & 80.602 & & 948 & & 396.167 & & 17.147 & & 4.328 & \\
\hline 2008 & 8.802 .989 & $3 \%$ & 72.963 & $-9 \%$ & 829 & $-13 \%$ & 472.722 & $19 \%$ & 11.000 & $-36 \%$ & 2.327 & $-46 \%$ \\
\hline 2009 & 9.030 .202 & $3 \%$ & 64.316 & $-12 \%$ & 712 & $-14 \%$ & 442.865 & $-6 \%$ & 12.133 & $10 \%$ & 2.740 & $18 \%$ \\
\hline 2010 & 10.030 .810 & $11 \%$ & 62.903 & $-2 \%$ & 627 & $-12 \%$ & 468.665 & $6 \%$ & 11.539 & $-5 \%$ & 2.462 & $-10 \%$ \\
\hline 2011 & 11.030 .939 & $10 \%$ & 69.227 & $10 \%$ & 628 & $0 \%$ & 515.932 & $10 \%$ & 12.540 & $9 \%$ & 2.431 & $-1 \%$ \\
\hline 2012 & 11.939 .620 & $8 \%$ & 74.871 & $8 \%$ & 627 & $0 \%$ & 522.636 & $1 \%$ & 11.983 & $-4 \%$ & 2.293 & $-6 \%$ \\
\hline 2013 & 12.484 .113 & $5 \%$ & 191.389 & $156 \%$ & 1.533 & $144 \%$ & 535.918 & $3 \%$ & 27.760 & $132 \%$ & 5.180 & $126 \%$ \\
\hline 2014 & 13.240 .122 & $6 \%$ & 221.366 & $16 \%$ & 1.672 & $9 \%$ & 546.367 & $2 \%$ & 30.886 & $11 \%$ & 5.653 & $9 \%$ \\
\hline 2015 & 13.999 .398 & $6 \%$ & 241.547 & $9 \%$ & 1.725 & $3 \%$ & 542.939 & $-1 \%$ & 31.750 & $3 \%$ & 5.848 & $3 \%$ \\
\hline 2016 & 13.775 .188 & $-2 \%$ & 286.068 & $18 \%$ & 2.077 & $20 \%$ & 528.706 & $-3 \%$ & 33.697 & $6 \%$ & 6.373 & $9 \%$ \\
\hline
\end{tabular}

Kaza Sıklığının yıllara göre değişimini gösteren grafik Şekil 6'da verilmektedir. Buna göre Türkiye geneli ve metal sektöründe 2012 yılına kadar kaza sıklığında yıllar bazında genelde azalma gözlenirken bu tarihten sonraki yıllarda ciddi artışlar görülmektedir. 2012 yılında metal sektöründe çalışan her 100.000 kişiden yaklaşık 2.293'ü iş kazasına maruz kalırken 2016 yılında bu değer yaklaşık üç kat artarak 6.373 çal1şan iş kazasına maruz kalmıştır. Yine benzer şekilde Türkiye genelinde 2012 yılında 627 çalışan iş kazasına maruz kalırken 2016 yılında 2.077 çalışan iş kazasına uğramıştır. Metal sektöründeki kaza sıklık değerleri Türkiye genelinin çok üstünde olmakla beraber kaza sıklığı en çok ana metal sanayi alt sektöründe yaşanmıştır. İş kazasıı sayısındaki artışın 2012 yılında yayınlanan İş Sağlığı ve Güvenliği Kanunu ile yakından ilişkisi vardır. Yayınlanan bu kanunun uygulamasında, iş kazası bildirim formunun elektronik ortamda alınmaya başlanması ile iş kazası geçiren ve bildirimi yapılan tüm sigortalı sayılarına ait veriler yayınlanmaya başlamıştır. Buna karşın 2012 ve öncesi yılları kapsayan uygulamada, iş kazası geçiren sigortalı sayılarına ait istatistikler verilirken ödemesi yapılıp kapatılan iş kazası vaka sayıları esas alınmaktaydı [23].

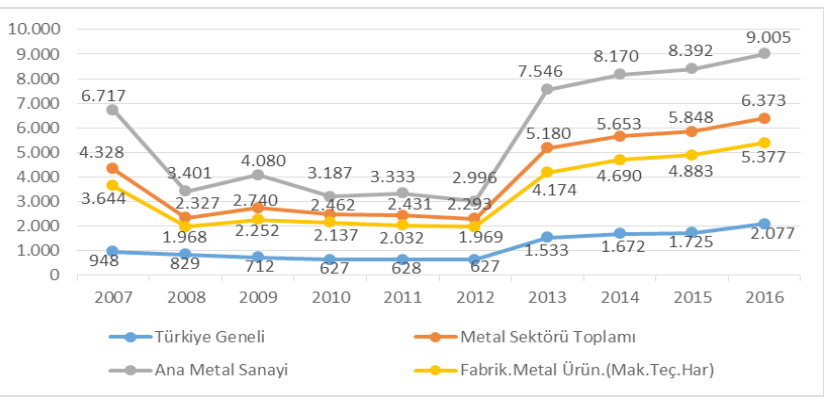

Şekil 6. İş Kazası S1klığı Dağılımı [17-26]

2007 - 2016 yılları arasında Türkiye geneli tüm sektörler toplamında ve metal sektöründe iş kazaları sonucu meydana gelen ölüm sayıları, sürekli iş göremezlik sayıları ve geçici iş göremezlik süreleri Tablo 5'de verilmiştir. Türkiye genelinde ve metal sektöründe ölüm sayıları yıllar bazında değişkenlik gösterirken, 2014 yılından sonra sürekli iş göremezlik sayısı ve geçici iş göremezlik sürelerinde dikkat çekici bir artış olmuştur. İş kazaları nedeniyle metal sektöründe son on yılın ortalamasına göre her y1l 55 çalışan hayatını kaybederken 230 çalışan ömür boyu sakat kalmış, 321.903 işgünü kaybı yaşanmıştır. Metal sektörünün Türkiye geneli sektörler toplamı içindeki ortalama payı ölüm sayısında yaklaşık \%4 iken sürekli iş göremezlik sayısı ve geçici iş göremezlik süresi içindeki payları sırasıyla \% 11 ve $\% 15^{\prime}$ dir. 
Tablo 5. Ölüm, Sürekli İş Göremezlik ve Geçici İş Göremezlik İstatistikleri [17-26]

\begin{tabular}{|c|c|c|c|c|c|c|c|c|c|}
\hline \multirow{2}{*}{ YILLAR } & \multicolumn{3}{|l|}{ Ölüm Sayısı } & \multicolumn{3}{|c|}{ Sürekli İş Göremezlik Sayısı } & \multicolumn{3}{|c|}{ Geçici İş Göremezlik Süresi (gün) } \\
\hline & Türkiye Geneli & Metal Sektörü & Oran $\%$ & Türkiye Geneli & Metal Sektörü & Oran \% & Türkiye Geneli & Metal Sektörü & Oran $\%$ \\
\hline 2007 & 1.043 & 60 & $6 \%$ & 1.550 & 182 & $12 \%$ & 1.934 .980 & 344.738 & $18 \%$ \\
\hline 2008 & 865 & 53 & $6 \%$ & 1.452 & 146 & $10 \%$ & 1.855 .980 & 237.141 & $13 \%$ \\
\hline 2009 & 1.171 & 13 & $1 \%$ & 1.668 & 126 & $8 \%$ & 1.572 .106 & 270.777 & $17 \%$ \\
\hline 2010 & 1.444 & 67 & $5 \%$ & 1.976 & 185 & $9 \%$ & 1.502 .871 & 242.909 & $16 \%$ \\
\hline 2011 & 1.700 & 90 & $5 \%$ & 2.093 & 202 & $10 \%$ & 1.757 .422 & 278.208 & $16 \%$ \\
\hline 2012 & 744 & 35 & $5 \%$ & 2.036 & 202 & $10 \%$ & 1.647 .127 & 229.695 & $14 \%$ \\
\hline 2013 & 1.360 & 69 & $5 \%$ & 1.660 & 208 & $13 \%$ & 2.357 .505 & 371.460 & $16 \%$ \\
\hline 2014 & 1.626 & 45 & $3 \%$ & 1.421 & 184 & $13 \%$ & 2.065 .962 & 329.018 & $16 \%$ \\
\hline 2015 & 1.252 & 58 & $5 \%$ & 3.433 & 395 & $12 \%$ & 2.992 .070 & 445.767 & $15 \%$ \\
\hline 2016 & 1.405 & 57 & $4 \%$ & 4.447 & 465 & $10 \%$ & 3.453 .702 & 469.314 & $14 \%$ \\
\hline Ortalama & 1.261 & 55 & $4 \%$ & 2.174 & 230 & $11 \%$ & 2.113 .973 & 321.903 & $15 \%$ \\
\hline
\end{tabular}

Çalışan sayısına oranla iş kazası sayısı ve sonuçları bakımından değerlendirildiğinde metal sektöründeki kazaların genelde orta şiddetli olduğu söylenilebilir.

Şekil 7'de verilen ve her 100.000 çalışana karş1lık ölüm sayılarını belirleyen Ölümlü Kaza Sıklığı incelendiğinde, özellikle 2012 y1lında belirgin bir düşüşün olduğu görülmektedir. 2016 yılında Türkiye genelinde her 100.000 çalışandan yaklaşık 10 kişi hayatını kaybederken metal sektöründe de 10 kişi yaşamını yitirmektedir. Bu da sektörde yaşanan ölüm vakaları sayısının Türkiye geneli ile benzer olduğunu göstermektedir.

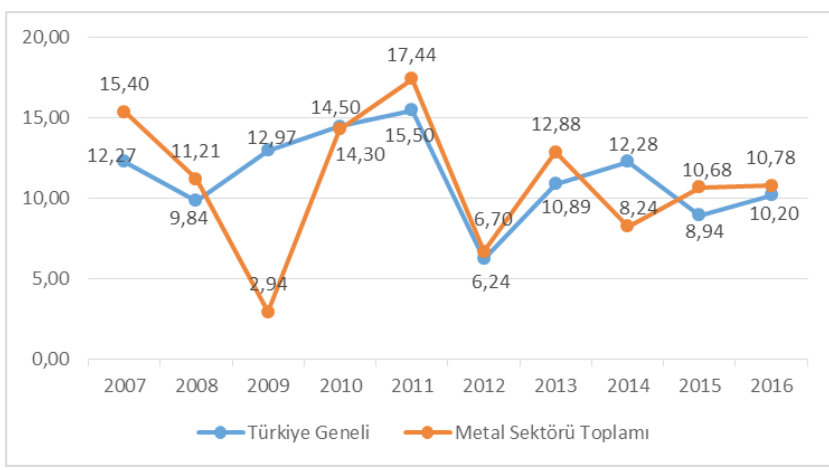

Şekil 7. Ölümlü Kaza Sıklığı Dağılımı [17-26]

Meydana gelen iş kazası ya da oluşan meslek hastalıkları neticesinde çalışanların meslekte kazanma gücünün en az \% 10 oranında azalmış olması halinde sürekli iş göremezlik durumu ortaya çıkmaktadır. İstatistik verilerinden elde edilen bilgilere göre hesaplanan Sürekli İş Göremezlik Kaza Sıklığı Türkiye geneli ve metal sektörü için Şekil 8'de verilmiştir. Grafik incelendiğinde Türkiye geneli ve metal sektöründe
2012 yılından 2014 yılına kadar sürekli iş göremezlik kaza sıklığında dikkate değer bir iyileşmenin olduğu gözlenmektedir. 2014 yılından sonra ise her iki değerde yaklaşık \%150200 oranında ciddi bir artış olmuştur. Şöyleki 2014 yılında metal sektöründe çalışan her 100.000 kişiden yaklaşık 38'i iş kazası sonucu sürekli iş göremez hale gelirken, 2016 y1lında bu değer 95'e yükselmiştir. Türkiye genelinde ise 11 olan sürekli iş görmez sayısı 34'e yükselmiştir. Metal sektöründe çalışanlar Türkiye geneli çalışanlardan yaklaşık üç kat daha fazla meslekte kazanma gücünün en az \% 10’unu kaybederek sürekli iş görmez haline gelmektedir.

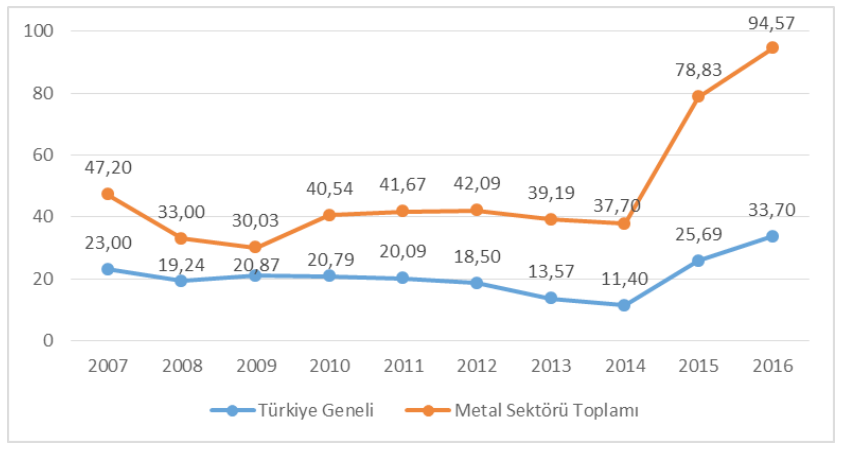

Şekil 8. Sürekli İş Göremezlik Kaza Sıklığı Dağılımı [17-26]

İş Kazası ya da meslek hastalıkları sonucu belirli sürelerde çalışılmaması durumu olarak ifade edilen Geçici İş Göremezlik süreleri için hesaplanan kaza sıklığı grafiksel olarak Şekil 9'da gösterilmektedir. Son on yıl içerisinde geçici iş göremezlik sürelerinde en büyük artış metal sektöründe $\% 57$, Türkiye genelinde $\% 37$ 'lik oranla 2012-2013 yılları arasında gerçekleşmiştir. 


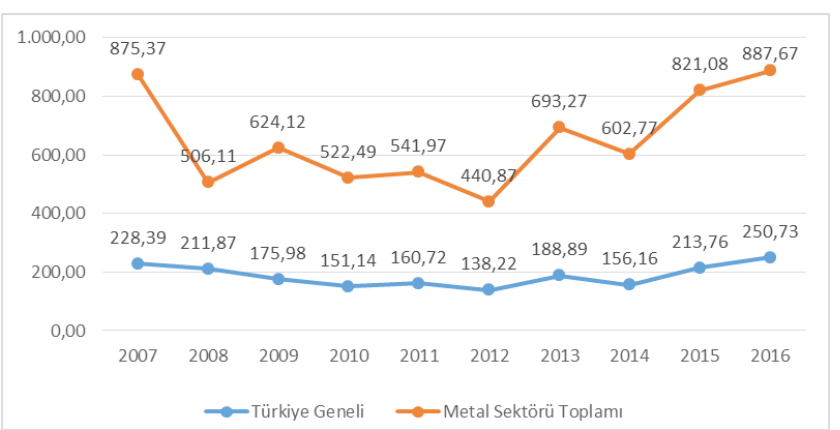

Şekil 9. Geçici İş Göremezlik Kaza Sıklığı Dağılımı [17-26]

Ülke genelinde meydana gelen iş kazalarının sayısı ile sektörde istihdam edilenlerin sayısının birlikte değerlendirildiği ve sektörler arasında karşılaştırma yapma imkanı sağlayan standardize iş kazası oranı hesaplamalarına ait değerler Şekil 10'da verilmiştir. Buna göre, Türkiye genelinde gerçekleşen iş kazalarını standardize oranı 100 olduğunda, metal sektöründe iş kazalarının yoğunluğu Türkiye geneline oranla genelde yaklaşık 3,5 kat fazla olup 2010 yılından sonra azalma eğilimi göstermektedir. Alt sektörler düzeyinde değerlendirildiğinde ana metal sanayinde standardize iş kazası oranı Türkiye geneline göre oldukça yüksek değerlere sahiptir.

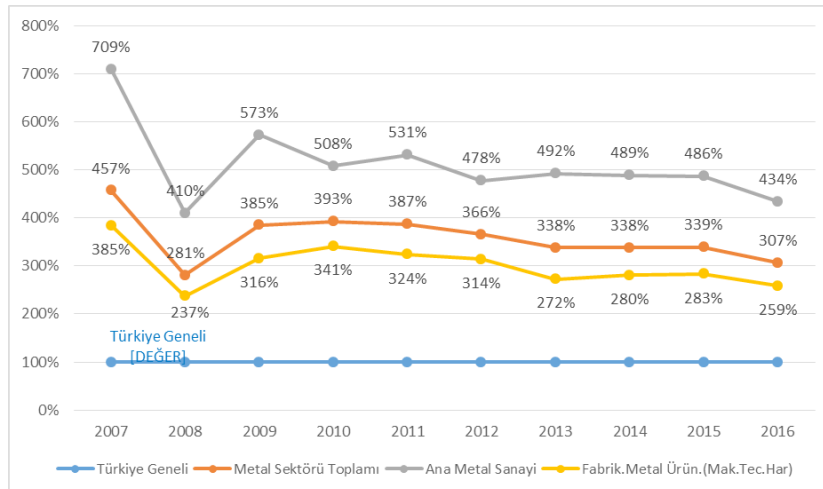

Şekil 10. Standardize İş Kazası Oranları Dağılımı [17-26]

Tablo 6'da Türkiye geneli ve metal sektörü için yıllar bazında istatistiki verilerden yararlanılarak hesaplanan İş Kazası Sıklık Hızı değerleri görülmektedir. Metal sektörü için

Tablo 6. İş Kazası Sıklık Hızı [17-26]

\begin{tabular}{|c|c|c|c|c|c|c|c|c|}
\hline \multirow{2}{*}{ Yillar } & \multicolumn{2}{|c|}{ Çalışan Sayısı } & \multicolumn{2}{|c|}{ İş kazası Sayısı } & \multicolumn{2}{|c|}{ Pirim Tahakkuk eden gün sayısı } & \multicolumn{2}{|c|}{$\begin{array}{l}\text { İş kazası sıklık hızı } \\
\text { (1.000.000 iş saati) }\end{array}$} \\
\hline & Türkiye Geneli & Metal Sektörü & Türkiye Geneli & Metal Sektörü & Türkiye Geneli & Metal Sektörü & Türkiye Geneli & Metal Sektörü \\
\hline 2007 & 8.505 .390 & 396.167 & 80.602 & 17.147 & 2.793 .420 .779 & 130.112 .920 & 3,61 & 16,47 \\
\hline 2008 & 8.802 .989 & 472.722 & 72.963 & 11.000 & 2.945 .664 .020 & 158.182 .657 & 3,10 & 8,69 \\
\hline 2009 & 9.030 .202 & 442.865 & 64.316 & 12.133 & 2.915.404.372 & 142.979 .145 & 2,76 & 10,61 \\
\hline 2010 & 10.030 .810 & 468.665 & 62.903 & 11.539 & 3.190 .289 .762 & 149.058 .466 & 2,46 & 9,68 \\
\hline 2011 & 11.030 .939 & 515.932 & 69.227 & 12.540 & 3.532 .389 .503 & 165.214 .655 & 2,45 & 9,49 \\
\hline 2012 & 11.939 .620 & 522.636 & 74.871 & 11.983 & 3.855 .795 .100 & 168.780 .692 & 2,43 & 8,87 \\
\hline 2013 & 12.484 .113 & 535.918 & 191.389 & 27.760 & 4.069 .831 .784 & 174.709 .738 & 5,88 & 19,86 \\
\hline 2014 & 13.240 .122 & 546.367 & 221.366 & 30.886 & 4.248 .428 .182 & 175.315 .678 & 6,51 & 22,02 \\
\hline 2015 & 13.999 .398 & 542.939 & 241.547 & 31.750 & 4.462 .091 .444 & 173.053 .403 & 6,77 & 22,93 \\
\hline 2016 & 13.775 .188 & 528.706 & 286.068 & 33.697 & 4.524 .501 .578 & 173.655 .062 & 7,90 & 24,26 \\
\hline
\end{tabular}

Tablo 7. İş Kazası Ağırlık Hızı [17-26]

\begin{tabular}{|c|c|c|c|c|c|c|c|c|c|c|}
\hline \multirow{2}{*}{ Y1llar } & \multicolumn{2}{|c|}{$\begin{array}{l}\text { Geçici İş Göremezlik Süresi } \\
\text { (gün) }\end{array}$} & \multicolumn{2}{|c|}{ Sürekli İş Göremezlik (gün) } & \multicolumn{2}{|c|}{$\begin{array}{l}\text { Sürekli İş Göremezlik Dere- } \\
\text { cesi Toplamı }\end{array}$} & \multicolumn{2}{|c|}{ Ölüm Vaka Sayısı } & \multicolumn{2}{|c|}{$\begin{array}{l}\text { İş kazası ağırlık hızı } \\
\text { (gün) }\end{array}$} \\
\hline & Türkiye Geneli & Metal Sektörü & Türkiye Geneli & Metal Sektörü & Türkiye Geneli & $\begin{array}{l}\text { Metal Sek- } \\
\text { törü }\end{array}$ & $\begin{array}{l}\text { Türkiye } \\
\text { Geneli }\end{array}$ & $\begin{array}{l}\text { Metal } \\
\text { Sektörü }\end{array}$ & \begin{tabular}{|l|} 
Türkiye \\
Geneli \\
\end{tabular} & $\begin{array}{l}\text { Metal Sek- } \\
\text { törü }\end{array}$ \\
\hline 2007 & 1.934 .980 & 344.738 & 1.550 & 182 & 59.457 & 6.981 & 1.043 & 60 & 636 & 1.267 \\
\hline 2008 & 1.855 .980 & 237.141 & 1.452 & 146 & 52.685 & 5.298 & 865 & 53 & 522 & 815 \\
\hline 2009 & 1.572 .106 & 270.777 & 1.668 & 126 & 61.300 & 4.631 & 1.171 & 13 & 641 & 626 \\
\hline 2010 & 1.502 .871 & 242.909 & 1.976 & 185 & 75.833 & 7.100 & 1.444 & 67 & 706 & 1.072 \\
\hline 2011 & 1.757 .422 & 278.208 & 2.093 & 202 & 78.054 & 7.533 & 1.700 & 90 & 721 & 1.149 \\
\hline 2012 & 1.647 .127 & 229.695 & 2.036 & 202 & 66.039 & 6.552 & 744 & 35 & 395 & 728 \\
\hline 2013 & 2.357 .505 & 371.460 & 1.660 & 208 & 52.825 & 6.619 & 1.360 & 69 & 507 & 991 \\
\hline 2014 & 2.065 .962 & 329.018 & 1.421 & 184 & 42.857 & 5.549 & 1.626 & 45 & 514 & 772 \\
\hline 2015 & 2.992.070 & 445.767 & 3.433 & 395 & 103.833 & 11.947 & 1.252 & 58 & 565 & 1.283 \\
\hline 2016 & 3.453 .702 & 469.314 & 4.447 & 465 & 134.403 & 14.054 & 1.405 & 57 & 665 & 1.404 \\
\hline
\end{tabular}


pirim tahakkuk gün sayısı, Türkiye genelinde o yıl çalışan başına düşen ortalama pirim tahakkuk eden gün sayısı bulunarak metal sektöründeki çalışan sayısı ile çarpılması sonucu elde edilen değer olarak alınmıştır.

İş Kazası Sıklık Hızının düşük olması hedeflenir. Şekil 11 'de İş Kazası Sıklık Hızı ve bunların yıllara göre değişimini gösteren eğrisel grafik incelendiğinde 2007 - 2012 yılları arasında genelde düşüş eğilimi olurken, 2012 yılından sonra iki kattan fazla meydana gelen artış devam etmiştir. 2016 y1lı içinde 1.000 .000 iş saatinde Türkiye genelinde ortalama 8 iş kazası meydana gelirken metal sektöründe 25 iş kazası gerçekleşmiştir. Yıllar bazında metal sektöründe yaşanan iş kazası Türkiye geneli ile karşılaştırıldığında, kaza sıklık hız değerlerinin son on yıllık periyotta genelde üç kattan fazla olduğu görülmektedir.

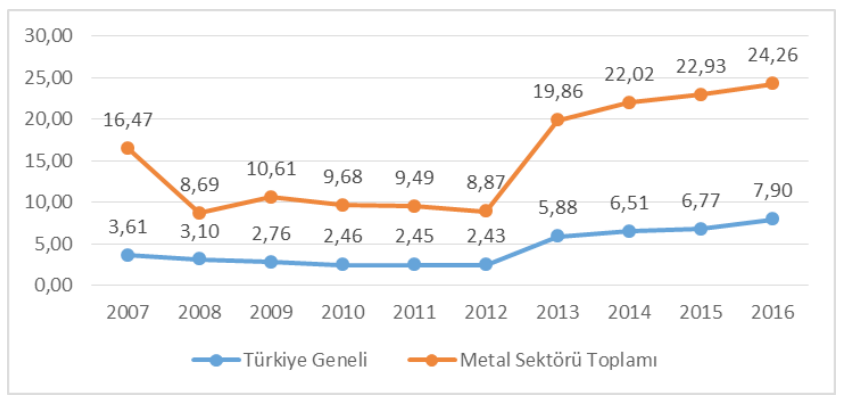

Şekil 11. İş Kazası Sıklık Hızı Dağılımı [17-26]

Türkiye geneli ve metal sektörü için son on y1llık istatistiki verilerden yararlanılarak hesaplanan İş kazası ağırlık hızı değerleri Tablo 7'de verilmektedir. Türkiye geneli için verilen sürekli iş göremezlik sayısının sürekli iş göremezlik derecesi toplamına olan oranından faydalanılarak metal sektörü için sürekli iş göremezlik dereceleri hesaplanmıştır.
İş Kazası Ağırlık Hızı ülke geneli, sektör veya bir işyerindeki kazaların ciddiyet önem derecesini göstermektedir. Türkiye geneli ve metal sektörü için Tablo 7'de hesaplanan İş Kazası Ağırlık Hızı ve yıllara göre değişiminin eğrisel grafik olarak gösterimi Şekil 12'de verilmiştir. Metal sektöründeki iş kazası ağırlık hızı 2009 yılı hariç neredeyse Türkiye genelinin iki katı seviyesindedir. 2012 yılında Türkiye genelinde 1.000 .000 saatte iş kazası nedeniyle 395 iş günü kayb1 olurken metal sektöründe 728 iş günü kaybedilmiştir. 2016 yılı içinde ise Türkiye genelinde 665 iş günü kaybı olurken metal sektöründe 1.404 iş günü kaybı yaşanmıştır. İş kazası ağırlık hızındaki artış, yaşanan kazaların daha ağır şekilde sonuçlandığını göstermektedir.

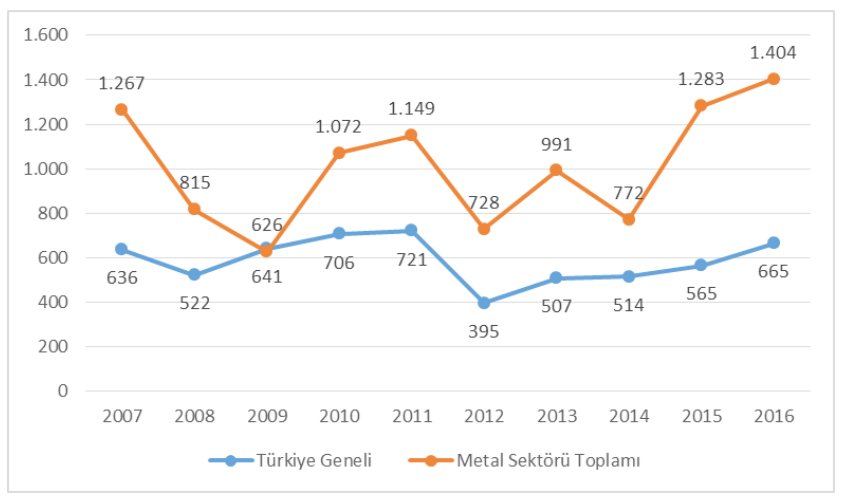

Şekil 12. İş Kazası Ağırlık Hızı Dağılımı [17-26]

Çalışma ve Sosyal Güvenlik Bakanlığınca yayınlanan Çalışma Hayatı İstatistiklerinden yararlanılarak elde edilen Türkiye geneli ve metal sektörü için son on yıl içinde gerçekleştirilen teftiş sayıları ve hesaplanan oranlar Tablo 8 'de verilmiştir. Teftiş sayıları ve oranlarına bakıldığında;

Tablo 8. İş Sağlığı ve Güvenliği Teftişi [27-33]

\begin{tabular}{|c|c|c|c|c|c|c|c|c|c|c|c|c|c|c|}
\hline \multirow[b]{2}{*}{ 总 } & \multicolumn{7}{|c|}{ Türkiye Geneli } & \multicolumn{7}{|c|}{ Metal Sektörü } \\
\hline & İşyeri Sayısı & $\begin{array}{c}\text { Toplam } \\
\text { Teftiş Sa- } \\
\text { y1sı }\end{array}$ & Oran & $\begin{array}{c}\text { Çalışan Sa- } \\
\text { yısı }\end{array}$ & $\begin{array}{l}\text { Teftişle Ça- } \\
\text { lışan Sayısı }\end{array}$ & Oran & $\begin{array}{c}\text { İncelenen } \\
\text { İş kazası } \\
\text { sayısı }\end{array}$ & $\begin{array}{l}\text { İşyeri } \\
\text { Sayısı }\end{array}$ & $\begin{array}{l}\text { Toplam } \\
\text { Teftiş } \\
\text { Sayısı } \\
\end{array}$ & Oran & $\begin{array}{c}\text { Çalışan Sa- } \\
\text { y1sı }\end{array}$ & $\begin{array}{c}\text { Teftişle } \\
\text { Çalışan } \\
\text { Sayısı } \\
\end{array}$ & Oran & $\begin{array}{c}\text { İncelenen } \\
\text { iş kazası } \\
\text { sayısı } \\
\end{array}$ \\
\hline 2009 & 1.216 .308 & 23.446 & $2 \%$ & 9.030 .202 & 875.186 & $10 \%$ & 5.599 & 45.503 & 5.251 & $12 \%$ & 726.795 & 243.770 & $34 \%$ & 1.605 \\
\hline 2010 & 1.325 .749 & 17.284 & $1 \%$ & 10.030 .810 & 2.211 .717 & $22 \%$ & 7.822 & 48.175 & 5.005 & $10 \%$ & 792.780 & 540.707 & $68 \%$ & 1.478 \\
\hline 2011 & 1.435 .879 & 15.902 & $1 \%$ & 11.030 .939 & 1.548 .973 & $14 \%$ & 4.222 & 52.054 & 3.890 & $7 \%$ & 858.802 & 333.746 & $39 \%$ & 698 \\
\hline 2012 & 1.538 .006 & 11.533 & $1 \%$ & 11.939 .620 & 1.069 .622 & $9 \%$ & 251 & 57.715 & 3.540 & $6 \%$ & 945.558 & 296.368 & $31 \%$ & 41 \\
\hline 2013 & 1.611 .292 & 8.858 & $1 \%$ & 12.484 .113 & 841.216 & $7 \%$ & 286 & 59.659 & 2.249 & $4 \%$ & 984.309 & 252.955 & $26 \%$ & 57 \\
\hline 2014 & 1.679 .990 & 14.174 & $1 \%$ & 13.240 .122 & 1.101 .484 & $8 \%$ & 363 & 58.981 & 2.127 & $4 \%$ & 1.005 .882 & 314.053 & $31 \%$ & 97 \\
\hline 2015 & 1.740 .187 & 13.296 & $1 \%$ & 13.999 .398 & 1.144 .387 & $8 \%$ & 285 & 56.865 & 1.879 & $3 \%$ & 964.459 & 254.206 & $26 \%$ & 37 \\
\hline 2016 & 1.749 .240 & 14.287 & $1 \%$ & 13.775 .188 & 1.123 .146 & $8 \%$ & 328 & 55.130 & 2.328 & $4 \%$ & 935.654 & 279.105 & $30 \%$ & 58 \\
\hline Ort. & 1.537 .081 & 14.848 & $1 \%$ & 11.941 .299 & 1.239 .466 & $10 \%$ & 2.395 & 54.260 & 3.284 & $6 \%$ & 901.780 & 314.364 & $35 \%$ & 509 \\
\hline
\end{tabular}


Türkiye genelinde işyeri teftiş sayılarında 2013 yılına kadar sürekli bir azalma gözlenirken teftiş edilen çalışan sayısı değişkenlik göstermekle birlikte genelde azalmıştır. Metal sektöründe teftiş edilen işyeri sayısı ve çalışan sayısında önemli miktarda azalma yaşanmıştır. 2009 yılında 5.251 adet işyeri teftiş edilirken 2016 yılında bu sayı 2.328'e düşmüş, 2010 yılında çalışanların \%68'i teftiş edilirken 2016 yılında \%30 çalışan teftiş edilmiştir. Teftişle incelenen iş kazası sayılarında da önemli miktarda azalma olmuştur.

Teftişle incelenen kazaların sonuçlarına göre dağlımı Şekil 13'de verilmektedir. Buna göre Türkiye genelinde teftişle incelenen kazaların \%22'si ölüm ve uzuv kaybı ile sonuçlanırken, metal sektöründe bu oran $\% 49$ 'dur.

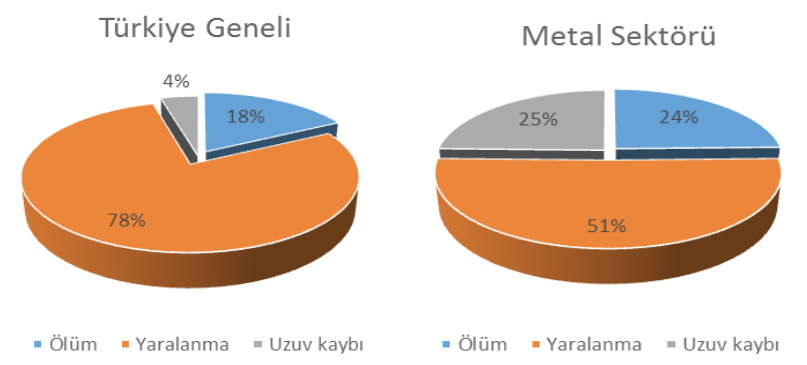

Şekil 13. Teftişle İş Kazalarının Sonuçlarına göre Dağılımı [33]

Türkiye geneli ve metal sektöründe teftişle incelenen iş kazalarının oluş nedenlerine göre oluşturulan grafik Şekil 14'de gösterilmektedir. En çok görülen kaza sebebi Tükiye genelinde $\% 35$ oranı ile kişilerin düşmesi sonucu oluşurken, metal sektöründe $\% 34$ oranı ile bir veya birden fazla cismin sıkıştırması, ezmesi, batması, kesmesi gibi seblerle oluşan kazalardır.

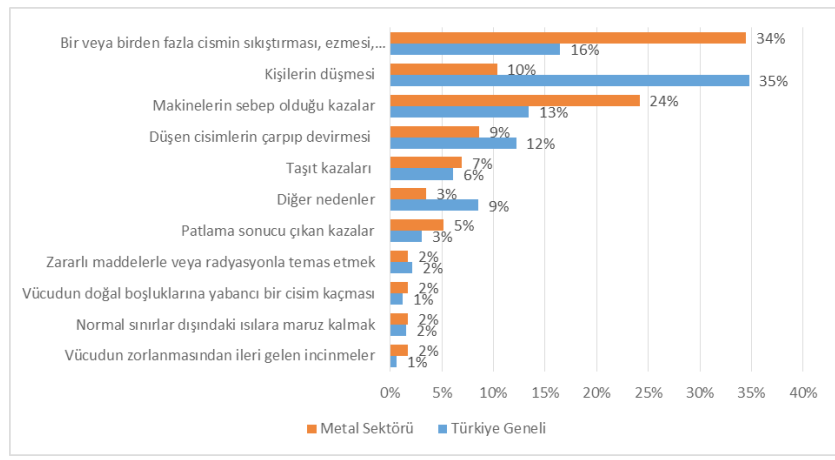

Şekil 14. Teftişle İncelenen İş Kazalarının Oluş Nedenleri [33]

Türk metal sektöründe yaşanan iş kazaları ile Avrupa genelindeki mevcut durumu mukayese etmek için, Avrupa Birliği geneli ile birliğe üye ülkelerden metal sektöründe ithalat ve ihraç girdilerine göre dünya sıralamasında ilk on'a giren Almanya, İsviçre, İtalya [3] ile ülkemiz arasında iş kazası sıklığı verileri karşılaş̧ırıılmıştır (Şekil 15, Şekil 16). Buna göre Avrupa birliği ülke geneli ortalaması ile incelenen diğer üye ülkeler arasında ana metal sanayinde İsviçre, fabrikasyon metal ürünleri imalatı sanayinde ise Almanya daha yüksek kaza sıklığı oranı değerine sahiptir. Ülkemiz ise 2012 y1lına kadar ana metal sanayinde Avrupa birliği üye ülkeleri ile yakın değerlerde olan kaza sıklığı oranında, bu yıldan sonra üye devletler ortalamasının yaklaşık 3,5 katı artış meydana gelmiştir. Fabrikasyon metal ürünleri imalatı sanayinde ise 2012 yılına kadar yarı değerlerde olan kaza sıklığı oranında bu yıldan sonra üye devletler ortalamasının üzerine çıkarak yaklaşık 1,7 kat artış meydana gelmiştir.

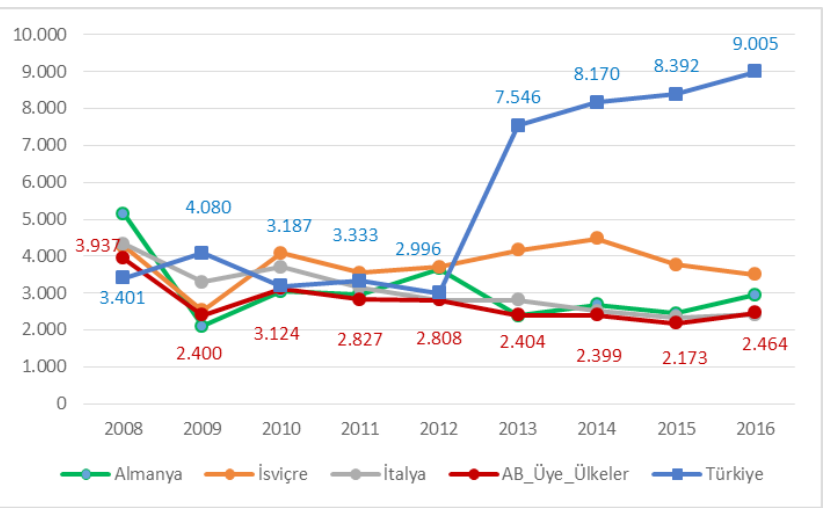

Şekil 15. Türkiye ve seçili AB ülkeleri ana metal sanayi iş kazası sıklık değerleri [34]

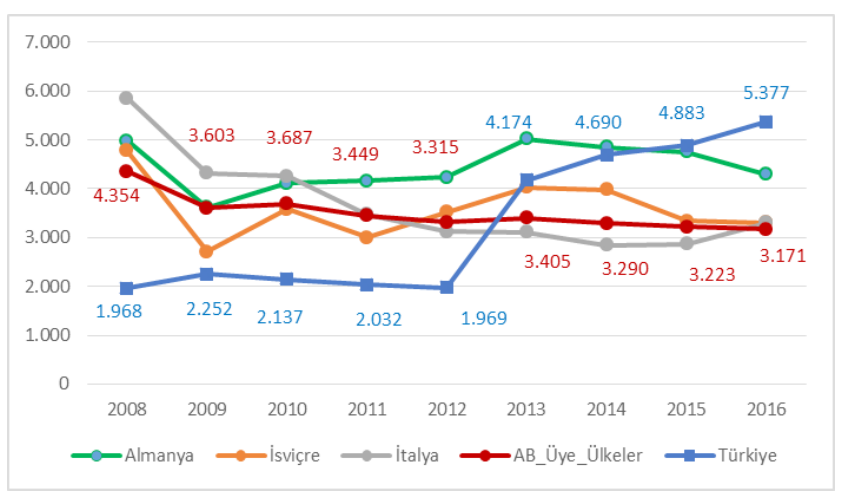

Şekil 16. Türkiye ve seçili $\mathrm{AB}$ ülkeleri fabrikasyon metal ürünleri imalatı sanayi iş kazası sıklık değerleri [34]

\section{IV.SONUÇ ve DEĞERLENDİRMELER}

Bu çalışmada Türkiye geneli ve metal sektöründe 2007 2016 yıllarını kapsayan son on yıl içerisinde meydana gelen 
iş kazası istatistikleri araştırılmış, elde edilen veriler uluslararası kabul görmüş çeşitli parametreler açısından incelenerek değerlendirilmeye çalışılmıştır. Buna göre;

Türkiye genelinde faaliyet gösteren işyerlerinin $\% 98$ 'i, metal sektöründe ise $\% 96$ 'sı çalışan sayısı elliden az olan mikro ve küçük ölçekli işletme niteliğinde iken Türkiye genelinde çalışanların \%59'u, metal sektöründe ise \%47'si bu işletmelerde görev yapmaktadır. Metal sektörü kendi içinde değerlendirildiğinde fabrikasyon metal ürünleri imalatının sektör içindeki payı \%82 olup bunun da \%66's1 bünyesinde 1-9 çalışanı bulunan mikro ölçekli işletme niteliğindedir. 6331 sayılı iş sağlığı ve güvenliği kanununa göre elliden az çalışanı bulunan işyerlerinde, iş sağlı̆̆ 1 ve güvenliği kurulu oluşturulması zorunlu değildir. Ancak tehlike sınıfına göre kısmi zamanlı iş sağlığı ve güvenliği uzmanı ve işyeri hekimi bulundurma zorunluluğu getirildi ise de bu hizmetlerin süresi ve kalitesinin yeterli olmadığ1 düşünülmektedir.

İstatistiki verilerden 2013 yılında çalışan sayısında fazla bir artış olmamasına rağmen iş kazası sayılarında yaklaşık iki buçuk kat artış olduğu görülmüştür. Bunun sebeplerinden biri olarak 2012 yılında çıkan 6331 sayılı iş sağlığı ve güvenliği kanunu ile iş güvenliği profesyonellerinin iş yerlerinde istihdam edilmesiyle birlikte iş kazalarının kayıt altına alınma oranında artış olduğu gösterilebilir. Fakat ölümlü iş kazalarında bu denli farkın görülmeme sebebi, bunların önceden de kayıt altına alınmasıdır.

Son 10 yıllık dönemde incelenen ve hesaplanan kaza sıklığı verileri Türkiye geneli ve metal sektörü için birlikte değerlendirilmiştir. Buna göre metal sektörü ölümlü kaza sıklığı bakımından Türkiye geneli ile çok yakın değerler seyretmesine rağmen genel kaza sıklığı, sürekli iş göremezlik sayısı ve geçici iş göremezlik süreleri kaza sıklığ bakımından Türkiye genelinin çok üzerinde yer almaktadır. 2016 y1lı içerisinde ülkemizde gerçekleşen tüm iş kazalarının $\% 11,78$ 'i, sürekli iş göremezliklerin $\% 10,46$ 's1, geçici iş görmezliklerin $\% 13,59$ 'u ve ölümlü iş kazalarının $\%$ 4,06'sı metal sanayi işlerinde gerçekleşmiştir. Bu durum sektörde yaşanan iş kazalarının sayısal bakımdan çok ve şiddetli olmasına rağmen ölümlü kaza şiddeti bakımından daha hafif olduğunu göstermektedir. Kaza sıklıkları genelde 2012 yılında çıkan 6331 sayılı iş sağlığı ve güvenliği kanunundan sonra ciddi oranda artmasına rağmen, iş kazalarının SGK'ya bildiriminde, iş verenlerin isteksiz ve çekingen davranmaları nedeniyle resmi verilerin gerçek değerlerin altında olduğu da düşünülmektedir.

Türkiye genelinde gerçekleşen iş kazalarının standardize oranı 100 olarak alındığında metal sektörü Türkiye geneline göre kazaların yoğun yaşandığ 1 bir sektör olma özelliğini taşımaktadır. Metal iş kolu alt sektörler düzeyinde incelendiğinde ise ana metal sanayi iş kazalarının en yoğun yaşandığı kaza oranına sahiptir.

İş kazası sıklık değerleri bakımından incelendiğinde metal sektöründe çalışanların Türkiye genelinde çalışanların üç katından daha fazla değerlere sahip olduğu görülmektedir. 2012 yılında çıkan iş sağlığı ve güvenliği kanunu ile birlikte metal sektöründe 2012 y1lında 8,87 olan 1.000 .000 iş saatine karşılık gelen kaza sayısı 2013 yılında 19,86, 2016 yılında ise 24,26'ya ulaşmıştır. Türkiye geneli iş kazası sıklık hızı ise 2016 yılında 7,90 değerindedir. Kazaların ciddiyet önem derecesini gösteren kaza ağırlık hızında da yine metal sektörü Türkiye ortalamasının üstündedir. 2016 yılı içinde ise Türkiye genelinde 665 iş günü kaybı olurken metal sektöründe 1.404 iş günü kaybı yaşanmıştır. Bu durum yaşanan kazaların metal sektöründe daha ağır şekilde sonuçlandığını göstermektedir Tehlikeli ve çok tehlikeli sınıfta yer alan metal sektöründe gözlenen yüksek iş kazası sıklık ve ağırlık hızının nedenleri olarak küçük işletmelerin gerekli iş sağlığ 1 ve güvenliği tedbirlerini almaması, düşük güvenlik kültürü, mesleki eğitimin ve kurumsal yapıların yetersizliği, koruyucusuz makine ve alet kullanımı, kişisel koruyucu ekipmanların kullanılmaması ve kayıt dışı istihdam gösterilebilir.

Diğer yandan iş sağlığı ve güvenliği teftiş sayılarına bakacak olursak, Türkiye geneli ve metal sektöründe teftiş edilen işyeri sayısı ve çalışan sayısında zaman içerisinde genelde azalma görülmektedir. 2009 y1lında metal sektöründe 5.251 adet işyeri teftiş edilirken 2016 y1lında bu sayı 2.328 'e düşmüştür. Teftiş sayıları azalırken kaza sayılarının artması bize kazaları önlemede teftişin ne kadar önemli olduğunu göstermektedir. 2016 yılında Türkiye genelinde işyerlerin $\% 1$ 'i, çalışanların $\% 8$ 'i teftiş edilirken, metal sektöründe işyerlerin $\% 6$ ' $\mathrm{s} 1$, çalışanların $\% 35^{\prime} \mathrm{i}$ teftiş edilmiştir. Buradan teftişlerin metal sektöründe daha çok orta ve büyük ölçekli işletmelerde yapıldığı anlaşılmaktadır. Metal sektöründe teftiş oranları Türkiye geneline göre daha iyi durumda olmakla birlikte, iş kazalarını önlemek amacıyla denetlenen işyeri ve çalışan sayısı açısından yetersiz düzeyde olan iş teftişi oranları arttırılmalıdır.

Türkiye metal sektörü ve Avrupa Birliği üye ülkeleri ortalaması ile ithalat ve ihracatta birliğin önde gelen ülkeleri, iş kazası sıklığı açısından incelendiğinde Almanya ve İsviçre gibi metal sektöründe önde gelen ülkelerin kaza sıklık değerleri Avrupa birliği ortalamasının üstündedir. Bu durum diğer Avrupa birliği üye ülkelerinden düşük kaza sıklı̆̆ gösterenlerin yaşanan kazaların bir çoğunu bildirmediği varsayımını ortaya koymaktadır. 2012 yılına kadar ülkemiz ana metal sanayinde ve fabrikasyon metal ürünleri imalatı sanayinde Avrupa birliği üye ülkeleri ile yakın ve hatta düşük 
kaza sıklığı oranları göstersede 2016 yılı verilerinde üye devletler ortalamasının üzerine çıkarak sırasıyla 3,5 ve 1,7 katı artış olduğu tespit edilmiştir. Görülen bu artışların 2012 yılında çıkan kanunla ve düzenlenen mevzuatlarla iş güvenliği uzmanlarının istihdam edilmesi ve kaza bildirimlerinin elektronik ortamda alınmaya başlanılması ile alakalı olduğu düşünülsede, gerçeğe daha yakın değerlerin bildirilmesinde hala sorunlar yaşanmakta ve bu yönde çalışmalar yapılması gerekmektedir.

İş kazaları ve meslek hastalıkları sonucu meydana gelen maddi ve manevi kayıplar çalışan, işletme ve toplum üzerinde mali, sosyal ve psikolojik yük oluşturmakta, yaşam kalitesini sarsmakta, ülke ekonomisi içinde büyük zararlara yol açmaktadır. Kazaların çoğu önlenebilir nitelikte olup, iş sağlığı ve güvenliği kültürünün yaşamın her alanında yaygınlaştırılması ile olası kazaların önüne geçilebilir. Öncelikli olarak güvenli çalışma ortamının sağlanması, iş sağlığ ve güvenliği koşullarının iyileştirilmesi, her kademede çalışanlara güvenlik eğitimlerinin verilmesi gerekmektedir. Günümüzde bilgi ve eğitimin önemi gün geçtikçe artmaktadır. Güvenlik kültürünün oluşabilmesi için eğitim, öncelikle ailede ve okullarda verilmeye başlanılmalıdır. Kişinin çalıştığı iş koluna yönelik eğitim alması, karşılaşabileceği iş kazası olasılığını düşürecektir. Eğitimin yanında denetimlerin de arttırılarak düzenli şekilde devam etmesi ve tespit edilen hususlara riayet edilmesi iş kazaların önlenmesinde büyük önem arz etmektedir.

\section{KAYNAKLAR}

[1] ILO-International Labour Organization, http://www.ilo.org/ global/topics/safety-and-health-at-work (Ağustos 2018).

[2] T.C. Çalışma ve Sosyal Güvenlik Bakanlığı, İş Teftiş Kurulu Bakanlığ 1 (2011). Metal sektöründe çalışan işçilerin çalışma koşullarının iyileştirilmesi programlı teftişi sonuç raporu, Yayın No:49, Ankara.

[3] Özden, A., Haçikoğlu, M., (2017). Ana metal sanayi sektörü, A\&T Bank Ekonomik Araştırmalar Departmanı, İstanbul.

[4] T.C. Bilim Sanayi ve Teknoloji Bakanlığı. Demir çelik raporu (2018), Sanayi Genel Müdürlügü, Sektörel Raporlar ve Analizler Serisi.

[5] Demir, E., (2009). Metal iş kolunda meydana gelen iş kazaları ve iş kazalarının oluşturduğu, kayıpların ekonomik yönden analizi. Yüksek Lisans Tezi, Marmara Üniversitesi Fen Bilimleri Enstitüsü, İstanbul

[6] T.C. Çalışma ve Sosyal Güvenlik Bakanlığı. İş Sağlığı ve Güvenliği Genel Müdürlüğü, KOBİ'ler için işs sağlığı ve güvenliği yönetim rehberi: risk değerlendirmesi, İSG performans izleme ve sağlık tehlikeleri Metal Sektörü.
[7] T.C. Çalışma ve Sosyal Güvenlik Bakanlığı, İş Sağlığı ve Güvenliği Genel Müdürlüğü. Meslek hastalıkları ve iş ile ilgili hastalıklar tanı rehberi.

[8] Saha, A., Kumar, S., Vasudevan, D.M., (2007). Occupational injury_surveillance: a study in a metal smelting industry. Indian Journal of Occupational and Environmental Medicine, 11 (3), 103-107.

[9] Türkiye Metal Sanayicileri Sendikası, MESS üyelerinde iş kazaları ve meslek hastalıkları istatistikleri 2016. https:// www.mess.org.tr/tr/haberler/is-sagligi-ve-guvenligi-alaninda-turkiyenin-en-kapsamli-arastirmasi-yayinlandi/ (Eylül 2018)

[10] Yağımlı, M., İzci, F.B., (2017). Türkiye'de makine ve teçhizatı hariç fabrikasyon metal ürünleri imalatı sektöründe yaşanan iş kazaları ve ölümlü iş kazası sayılarının tahmini. Karaelmas $\dot{I}_{S ̧}$ Sağllğ̆ ve Güvenliği Dergisi, 1 (1), 9-15.

[11] Gülhan, B., İlhan M.N., Civil E.F., (2012). Occupational accidents and affecting factors of metal industry in a factory in Ankara. Turkish Journal of Public Health, 10 (2), 76-85.

[12] Bull, N., (2007). Mandatory use of eye protection prevents eye injuries in the metal industry. Occupational Medicine, 57, 605-606.

[13] T.C. Çalışma ve Sosyal Güvenlik Bakanlığı, İş Sağlığı ve Güvenliği Genel Müdürlüğü (2016). Metal sektörü kişisel koruyucu donanım rehberi. Ankara 2016.

[14] T.C. Çalışma ve Sosyal Güvenlik Bakanlığı, (2012). İş sağlığı ve güvenliğine ilişkin işyeri tehlike sınıfları tebliği. Resmi Gazete Say1:28602,

[15] International Labour Office (ILO), (1998). 16th international conference of labour statisticians, Geneva,

[16] Eurostat European Commission, (2013). European statistics on accidents at work (ESAW) - summary methodology. Eurostat Methodologies \& Working Paper, 2013 Edition.

[17] Sosyal Güvenlik Kurumu (SGK), 2007 SGK İstatistik Y1llıklar1. 2007, Ankara

[18] Sosyal Güvenlik Kurumu (SGK), "2008 SGK İstatistik Y11l1kları", 2008, Ankara.

[19] Sosyal Güvenlik Kurumu (SGK), "2009 SGK İstatistik Y11l1kları", 2009, Ankara.

[20] Sosyal Güvenlik Kurumu (SGK), "2010 SGK İstatistik Y11likları", 2010, Ankara.

[21] Sosyal Güvenlik Kurumu (SGK), "2011 SGK İstatistik Y1llıkları", 2011, Ankara.

[22] Sosyal Güvenlik Kurumu (SGK), "2012 SGK İstatistik Y11likları", 2012, Ankara.

[23] Sosyal Güvenlik Kurumu (SGK), "2013 SGK İstatistik Y11likları", 2013, Ankara.

[24] Sosyal Güvenlik Kurumu (SGK), "2014 SGK İstatistik Y11likları", 2014, Ankara.

[25] Sosyal Güvenlik Kurumu (SGK), "2015 SGK İstatistik Y1llikları", 2015, Ankara. 
[26] Sosyal Güvenlik Kurumu (SGK), "2016 SGK İstatistik Y1llikları", 2016, Ankara.

[27] T.C. Çalışma ve Sosyal Güvenlik Bakanlığı, (2010), "Çalışma Hayatı İstatistikleri”, 2010, Ankara.

[28] T.C. Çalışma ve Sosyal Güvenlik Bakanlığı, (2011), "Çalışma Hayatı İstatistikleri”, 2011, Ankara.

[29] T.C. Çalışma ve Sosyal Güvenlik Bakanlığı, (2012), "Ça1ışma Hayatı İstatistikleri”, 2012, Ankara.

[30] T.C. Çalışma ve Sosyal Güvenlik Bakanlığı, (2013), “Çalışma Hayatı İstatistikleri”, 2013, Ankara.
[31] T.C. Çalışma ve Sosyal Güvenlik Bakanlığı, (2014), "Çalışma Hayatı İstatistikleri”, 2014, Ankara.

[32] T.C. Çalışma ve Sosyal Güvenlik Bakanlığı, (2015), "Çalışma Hayatı İstatistikleri”, 2015, Ankara.

[33] T.C. Çalışma ve Sosyal Güvenlik Bakanlığı, (2016), "Çalışma Hayatı İstatistikleri”, 2016, Ankara.

[34] Eurostat - European Statistical Office http://appsso.eurostat. ec.europa.eu/nui/submitViewTableAction.do (Eylül 2018). 